\title{
Dividend Payout and Firm Performance: Evidence from a Frontier Market
}

\author{
B.H.V. Mendis ${ }^{1 *}$ and M. R. P. Wijesinghe ${ }^{2}$ \\ 12 Department of Finance, University of Kelaniya, Sri Lanka. \\ * Corresponding Author: ruwanmrp@kln.ac.lk
}

\begin{abstract}
This study attempts to identify the impact of dividend payout on the market and financial performances of listed entities in Colombo Stock Exchange (CSE). We selected 25 listed entities for this study for 06 years from the year 2014 to 2019. Dividend payout used as a key independent variable while Earning volatility, Net working capital, Capital structure and firm size considered as control variables. Stock return and Market Value Added (MVA) are used as the proxies for firm's market performance while return on equity, return on Assets and Economic Value Added (EVA) are used as proxies for financial performance. In terms of analysis, panel regression was applied in order to identify whether there is an impact of dividend payout on firm financial and market performance. The findings revealed that there is a significant positive influence of dividend payout on firm stock return, return on equity, return on assets and EVA. Our findings become original as the first study to employ market performance indicators in this phenomenon. Henceforth, these findings are valuable for the policy makers specially for corporate managers and investors for their decision making.
\end{abstract}

Keywords: Dividend payout, Financial performance, Market performance, Sri Lanka.

\section{INTRODUCTION}

Corporate finance involves with 03 fundamental decisions: Investment decisions, Finance decisions and dividend decisions. Investment decision in other words capital budgeting mainly concern on amount of funds to be deployed in the investment opportunities and Financing decision concern with how these assets should be financed. Dividend decision may arise when the firm begins to generate the profits. Dividend is the benefit to the shareholders in return for their investment and the risk that they bear. It determines how much of the profit should distribute among the investors and how much of profit need to be retain with the entity.

Numerous scholars (David,2011; Amollo, 2013; Ajanthan,2013) paid their attention on study of dividend policy because its known as unsolved issue in corporate finance. Brealey (2002) lists dividends as one of the ten important unsolved problems in corporate finance. The profitability is one of the important factors that influence the dividend payout, and it has evident that highly profitable firms tend to pay high dividends which lead to high payout ratio (Amidu, 2006).

Black (1976) concluded about the dividend policy as "the harder we look at the dividends picture, the more it seems like a puzzle, with pieces that just do not fit together" which is still a valid statement. Even signaling theory, Bird in hand theory, agency theory and dividend irrelevance theory (Gordon,1963; Fama,1991; Miller \& Midigliani,1961) were able to indicate the corporate behavior of dividend payout but it's still an unsolved question.

When making capital structure decisions, corporate managers may face dilemma of whether the payout policies effect on the firm performances or not. Prior studies concluded with contradictory evidence on the impact of dividend payout on firm performance. On one hand Majanga (2015) and Sharif et al., (2011), 
provide strong evidence that firm dividend payout positively impacts on its share price and on the other hand, Chen et al (2002), Irum et al., (2012) and Uddin, (2005) concluded that dividend payout has no significant impact on firm share price. Almasum, (2014) revealed that the relationship between dividend yield has significant negative effect on firm performance. Even though numerous studies conducted on dividend policy and firm performances in developed economies (Narang, 2018; Olufade, 2018; Manjunatha, 2018), those studies used only traditional measures of financial performance such as, return on equity (ROE) and Return on asset (ROA). Even in Sri Lankan context, majority of the studies used ROA and ROE as proxy for firm's performances (Balasundaram, 2013; Paviththira, 2015; Wijekoon and Senevirathna, 2019; Silva and Perera, 2020; Priya, and Nimalathasan, 2013).

With this backdrop, this study attempts to address the above gap by examining the impact of dividend payout on both firm's financial and market performance measures, based on emerging market companies using a sample from CSE. Therefore, this study become original by employing financial performance measures along with the market performance indicators in the context of Sri Lanka. The impact on firm's market performance is measured on market-based performance indicators, namely stock return and market value added (MVA) and impact on firm's financial performances is measured through, return on Equity (ROE), return on asset (ROA) and Economic Value Added (EVA). With this background, the main objective of this study is to investigate whether there is a significant positive impact of dividend payout on firm's financial and market performance.

The outcome of the study is imperative for managers as it able to identify at what extend dividend payout will influence the performances and the value of the firm. That is, it helps management to make decision on dividend policies and they will be able to come up with payout policies that will compromise between short term stakeholder interest and the survival of the firm. Furthermore, the study is important for the policy makers, especially for corporate managers and investors as they can employ the findings to increase the value of the firm.

The remaining part of the study is structured as follows, the second section evaluates the existing literatures regarding corporate behavior of dividend policy and different views on dividend payout and the firm's performances. Third Section discusses the empirical methodology and results, and findings are discussed in the fourth section of the article. Finally, conclusions, recommendations and direction for further research is given at the final section of the article.

\section{LITERATURE REVIEW}

There are numerous studies conducted in order to indicate the relationship between the dividend payout and the firm performances. However, before moving to the empirical studies, first we will discuss the applicable theories relating to the current study. We can see two broad categories of dividend theories namely, dividend relevancy theories and irrelevancy theories.

Gordon (1963) developed the Bird in Hand theory which explained that due to uncertainty in the business environment investors prefer more dividend over the capital gain because capital gain involve with risk since it relates to the future. Shefrin (1984) further conclude that shareholders more prefer series of small gains rather than one-time big gain such as capital gain. Therefore, investors are willing to pay higher price for firm with dividend payment. Black (1990) also indicate that shareholders more prefer dividend payout because it prevent them from consuming their own capital.

Signaling theory indicate that dividend payout will provide signals to the investors regarding the company's financial health. Therefore, high dividend pays indicate business have a high cash flows in the future. As a result of that higher dividend signals will leads to have 
a higher firm value (Bhattacharya,1979). Lintner (1956) indicate that companies have propensity of increasing the dividends when their managers were of the belief that increasing earning is permanent. This denotes that higher dividend payout is a suggestion of the sustainability of earning in the long run. In the same way reducing dividend payments implies unfavorable future prospects and will have a tendency of seeing the reduce in the stock prices. Therefore, dividend is credible signaling mechanism as a result of the implicit costs involved.

Under the perfect market conditions there is no conflict of interest between the managers and the outside shareholders is the one of an assumption in dividend relevance theory. But in real world this assumption might be doubtful. As per the agency theory if the earning is not distributed among the outside shareholders, they might be diverted by managers for personal utility that provide private benefits for the managers. Therefore, shareholders may prefer more dividends and firms with substantial dividend payments will improve the value of the firm by decreasing the amounts of funds available to managers. Furthermore, agency theory indicates that firm's investment policy and the firm's dividend policy are negatively correlated. This implies that increasing the dividend payout will reduce the firm's overinvestment problem, which will lead to increase the value of the firm.

Behavioral based theory explains the reasons behind the attraction of investors for dividends and explain different behavioral factors such as demographic factors (For example age, income, and retirement status) that may influence investor's dividend payments preferences. Shefrin (2010) concluded that older, retired, and lower income level households were more prefer dividend paying stocks and younger investors with moderate or high level of income didn't have much preference on dividend paying stocks.

When it has come to the dividend irrelevance theories, dividend irrelevance theory (Modigliani, and Miller, 1958,1961) argued that in a perfect capital market rational investor behavior and perfect certainty the dividend payout is unrelated to its firm value. This theory assumed that in ideal business world there is no conflict of interest between managers and the shareholders, and all the information are free, and all the investors have equal access and there is no transaction cost involve with when they buying and selling shares and there is no difference between the tax rates for dividends and the tax rates for capital gain. Therefore, irrelevance theory conclude that dividend policy has no effect on the value of the firm. However, later on MM theory explained three scenarios regarding the dividend payments.

After analyzing the theoretical background of the importance of dividend payment and its impact on performance as well as on the value, we discovered that the presence of diverse and contradictory arguments relating to the ultimate impact of dividend payments on firm performance. With this position, next part of our review analyses the empirical studies conducted relating to the impact of dividend payout on firm performance.

Narang (2018) examined the relationship between the dividend policy and financial performances of the firm listed in national stock exchange based on firm financial performance measures, return on asset, and Return on equity. The data was collection were limited to 20 firm listed in national stock exchange for a period of 2012 to 2017 . The main methodologies used for data analysis were correlation and regression analysis. The results of the study show that dividend policy measures are not significantly correlated with the earning per share, ROE and ROA.

It is identified that growing firms tend to pay less dividend as they need more funds in order to finance their growth (Abor, 2006). Hat is firms will retain greater proportion from their earnings by paying low dividends. Findings of the Abor, (2006) further emphasis that, firms are paying dividends in order to minimize the cost associated with the agency problem. Therefore, if the institutional holding is higher, the dividend payout ratio will be lower. 
Furthermore, Uwalowajimoh and Anijesushola (2012) studied effect of dividend payout on performance of the companies listed in Nigeria stock exchange. Ownership structure return on equity and the firm size taken as an independent variable and the dividend payout ratio taken as dependent variable. This study observed that the performance of the company has a significant impact on the dividend payout ratio. Also, the findings conclude that there is a significant positive relationship between the ownership structure and the performance of the entity. $\mathrm{He}$ further suggested that larger companies tend to be pay more dividends because they were having easier access to the external financing therefore, they were relying less on internal capital.

Anton (2016) examines the impact of dividend payout on firm value based on the evidence from the Romanian capital market over the period of 2001 to 2011. In his study he concludes that a positive correlation coefficient between the dividend payout ratio and the firm value. He also found that negative correlation between the debt ratio and the dividend payout which imply that more levered firms are likely to be paying low level of dividends.

As per Bhattacharya (1979), payment of high dividend indicate that the business is having high amount of cash flows in the future and as a result of that higher dividend signaled higher firm value. Lintner (1956) indicates that companies have propensity of increasing the dividends when their managers were of the belief that increasing earning is permanent. This denotes that higher dividend payout is a suggestion of the sustainability of earning in the long run from a stock.

Furthermore, in the Indian context, Manjunatha (2018) examined the relationship between the dividend payout (measured by dividend payout ratio) and financial performance measured by ROA. The results revealed that there is a statistically significant negative relationship between the dividend payout and firm's financial performances. Gharaibeh et al. (2017) have empirically investigated the factors that determine the value of the firm based on Saudi stock exchange. The study concludes that market capitalization, growth opportunities and the profitability of the firm are the key determinants of firm value and variables such as dividend payout, leverage and the firm size are not significant determinants of the market value of the firm.

As evident from the literature, ample studies are available which examine the corporate behavior of dividend policy and come up with contradictory conclusions on the impact of dividend payout on firm performances. As we can identify through the prior studies, the measurements of performance are limited to the financial performance measurement indicators. That is, they used common financial performance indicators such as return on asset, and return on equity etc.

With the inconclusive findings related to the global context, let us discuss the studies relating to Sri Lankan context. Sugathadasa, (2018) conducted a study of the dividend policy on share price volatility in CSE. The sample size consists with 30 public listed companies at CSE and dividend payout, dividend yield, firm size and asset growth have been used as dimensions of dividend policy. The findings clearly revealed that there is a negative insignificant relationship between the dividend payout ratio and the share price volatility. Beside that dividend yield also negatively and insignificantly effect on the share price volatility.

Furthermore, in the Sri Lankan context, Balagobei (2015) analyzed the relationship between the dividend policy and the shareholder's wealth. Sample of this study limited to the manufacturing sector with 12 listed entities. Shareholder's wealth measured based on the EPS and DPS, payout ratio and $\mathrm{ROE}$ is the independent variables. The results of the study revealed that DPS, payout ratio and the ROE have a significant positive relationship with the shareholder's wealth. Based on the findings he concludes that companies should have good and robust dividend policies because ultimately it will 
attract investments into the organization and enhance the shareholder's wealth.

Using a sample of 82 listed companies in CSE from period from 2013-2017 Wijekoon and Senevirathna (2019), studied the impact of dividend policy on firm performance of listed companies in CSE. They have used return on equity and return on assets as the performance indicators and dividend policy is measured by dividend pay-out ratio and earning per share. This study also investigates the influence of dividend policy only on firm financial performances. Their findings suggest that there is significant positive impact from dividend on firm performance. Priya, and Nimalathasan, (2013), investigated the impact of dividend policy limited to Hotels \& Restaurant companies of Sri Lanka from 2008 to 2012. Furthermore, their findings also represent only financial performance measures limiting to ROA and ROE. Recently, De Silva and Perera, (2020) investigated the impact of dividend policy on firm performance at CSE for a period of 2011 to 2019. However, their findings are not clear, and the study is limited to 22 finance sector companies to measure only the financial performance. Based on these evidences it seems that the impact of dividend policy has been limited to investigate in few sectors with limited to financial performance measures.

In summary, based on the analysis of prior studies, it is evident that the impact of dividend policy on firm performance still remains as inconclusive with contradictory findings. Especially, in the context of Sri Lanka there is limited studies conducted limiting to few sectors using only financial performance indicators. Henceforth, it's become vital to examine the impact of dividend policy on firm performance using both financial and market performance gauges.

\section{RESEARCH METHODOLOGY}

\section{Sample Data and Data Collection}

This study uses explanatory research design in order to investigate the research problems and testing the hypothesis in the study. The population of this study consist with 290 companies listed in CSE that represent the GCIS industry groups. The sample is a subset of the population which represent the entire group as a whole. Sample of 25 companies were selected based on highest market capitalization of the CSE as at 2020. The selected companies represent $50 \%$ of the market capitalization at CSE on that day. However due to unavailability of the data in calculating the required ratios, some of the highest market capitalized companies were not considered. The financial companies also excluded from the sample because different characteristics compared to the companies in the other industries.

\section{Hypothesis Development}

Based on the theoretical review and the prior studies identified, following hypotheses can be derived.

$\mathrm{H}_{1}$ : There is a significant positive influence of dividend payout on firm Stock return.

$\mathrm{H}_{2}$ : There is a significant positive influence of dividend payout on firm Market Value Added $\mathrm{H}_{3}$ : There is a significant positive influence of dividend payout on firm Return on equity.

$\mathrm{H}_{4}$ : There is a significant positive influence of dividend payout on firm Return on Assets.

$\mathrm{H}_{5}$ : There is a significant positive influence of dividend payout on firm Economic Value added.

As per the identified hypotheses, we can develop the following conceptual framework.

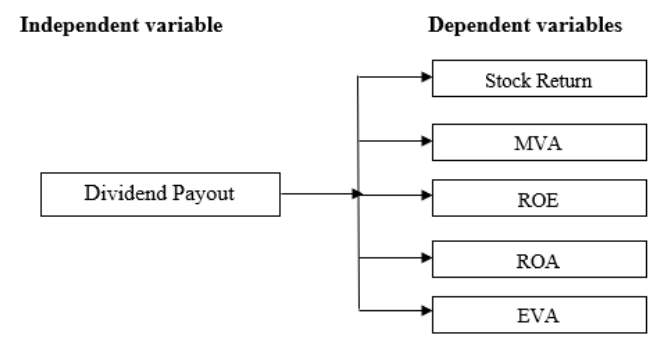

Figure 01: Conceptual Framework 


\section{OPERATIONALIZATION OF VARIABLES}

This part is providing details on how identified variables are calculated. Based on the evidence of the previous studied (Allayannis, 2003; Paviththira, 2015; Hussainey,2011). We used four control variables in this study namely Earning Volatility, Net Working Capital, Capital Structure and Firm Size. The calculation of dependent and independent variables are as follows.

- Return on Assets - ROA is an indicator of profitability of the firm relative to its total assets. It derived by Net income of the firm divide by the average total assets.

Return on Assets $($ ROA $)=\frac{\text { Net income }}{\text { Average Total Assets }}$

- Return on equity - ROE is net income of the firm relative to its total shareholder's equity.

Return on Equity $(\mathrm{ROE})=\frac{\text { Net income }}{\text { shareholder's equity }}(2)$

- $\quad$ Stock Return - Growth rate of share price

Stock Return $=\frac{\mathrm{P}_{1}-\mathrm{P}_{0}}{\mathrm{P}_{0}}$ (3)

- Market Value added - MVA is the difference between the market value of equity and debt of the firm and the book value of equity and the debt of the firm.

MVA= Market Value of Debt and Equity Book value of Debt and Equity (4)

- Economic Value Added - EVA is the difference between net operating profit after tax and the firm cost of capital.

EVA $=$ NOPAT $-($ WACC $\times$ Invested Capital $)$

- Dividend payout - Dividend payout ratio will indicate how much of total dividend paid out to its shareholders relative to net income of the firm. Dividend payout ratio can be calculated as dividend per share
(DPS) divide by the earning per share (EPS).

Dividend Payout $=\frac{\text { DPS }}{\text { EPS }}(6)$

- Earning Volatility - Earning volatility represent the earning fluctuation of the firm. It shows how stable or unstable the firm's earnings. Measure for earning volatility for each firm is the Square root of variance of quarterly EPS (Allayannis, 2003).

Earning Volatility $=\sigma \sqrt{\mathrm{T}}$

- Net Working Capital - This will indicate the short-term liquidity position of the firm. Net Working capital is the difference between the current assets and current liabilities.

Net Working Capital $=$ Current Assets Current Liabilities

- Capital Structure - Leverage Ratio indicate the combination of equity and the debt of the organization. The formula for the firm capital structure can be explained as follows,

Capital Structure $=\frac{\text { Total Debt }}{\text { Total Equity }}(9)$

- Firm size - Firm size is considered as control variable which will be calculated as natural logarithm of total assets.

$\log _{10}$ (Total Assets) (10)

Table 01 below provides the summary of the variable calculation. 
Table 01: Variable Calculations

\begin{tabular}{ll}
\hline Dependent Variables \\
\hline Stock Return & $\left(P_{1}-P_{0}\right) / P_{0}$ \\
MVA & $\begin{array}{l}\text { Market Value of Debt and Equity } \\
\text { ROE }\end{array}$ \\
& Neok value of Debt and Equity \\
& Equity \\
ROA & Net Income / Average Total \\
& Assets \\
EVA & Net Operating Profit after tax- \\
& (WACC x Invested Capital) \\
\hline Independent Variables \\
\hline Dividend Payout & Dividend per share / Earnings per \\
& share (DPS / EPS) \\
\hline Control Variables \\
\hline Earning & $\sigma \sqrt{T}$ \\
Volatility & Current Assets - Current \\
Net Working & Liabilities \\
Capital & Total Debt / Total Equity \\
Capital & Log value of Total Assets \\
Structure & \\
Firm Size &
\end{tabular}

\section{Regression Analysis}

This study employed panel regression model to test the hypotheses of the study. Since, this involves five dependent variables, five separate multiple regression analysis were done the analyses the data using Stata 13 software. The summary of the tested models are as follows.

Model 1: Stock return as the dependent variable

Model 2: Market value added as the dependent variable.

Model 3: Return on equity as the dependent variable.

Model 4: Return on asset as the dependent variable.

Model 5: Economic Value added as the dependent variable.

However, before dealing with the panel regression analysis, we tested for the diagnosis tests which a preliminary requirement for the analysis. For this purpose, it is vital to examine the existence of unit root in the data series. To test that, Levin, Lin \& Chu test were employed. The results indicated that, variables do not have unit root and the outcome of these tests are attached with Appendix 01. Then we tested for the multicollinearity and the results indicate that no multicollinearity and the results are attached with Appendix 02. More importantly, as the next step we tested for fixed and random effect models. Based on the Hausman test results fixed effect model is suitable for all models except model 01 . Then we need to test for time fixed effect in order to see whether fixed time effects are needed when running the fixed effect model. Based on the test results, for the model 02 and 04 fixed time effects are needed when running the model. For model 01 Breusch-Pagan Lagrange multiplier (LM) test were employed in order to decide between a random effect regression and a simple OLS regression. Based on the test results simple OLS regression model is suitable for model 01 . The results of the Hausman test are attached with appendix 03. Finally, we tested the normality of the data series tested from Jarque-Bera test and the test results indicate that population is normally distributed (See appendix 04). After satisfying all the pretests we applied the following panel regression model to each dependent variable.

$\mathrm{Y}=\alpha+\beta_{1}$ Divpay $+\beta_{2}$ Earnvol $+\beta_{3} \mathrm{NWC}+$ $\beta_{4}$ Capstru $+\beta_{5}$ Size $+\varepsilon_{\mathrm{i}}(10)$

Where, $\mathrm{Y}=$ Firm performance; Divpay = Dividend payout; Earnvol = Earnings Volatility; NWC = Net Working Capital; Capstru $=$ Capital Structure; Size $=$ Firm Size and $\varepsilon_{\mathrm{i}}=$ Error term

\section{RESULTS AND ANALYSIS}

As per the descriptive statistics (See Table 02 below) the mean value and standard deviation of stock return indicate $-0.05 \%$ and $25 \%$ respectively. This suggest that Stock return, it could deviate by $+/-25 \%$ which giving values between $-25.05 \%$ and $24.95 \%$. Minimum and maximum values of stock return are $-40 \%$ and $54 \%$. Similarly, Economic Value Added reported mean value and standard deviation of 
-2116.94 and 4117.42. This suggest that Economic Value Added of the firm could be deviate by +/- 4117.42 which give values between $-6,234.36$ and 2,000.48. When considering the independent variables, Dividend payout is the primary independent variable in analyzing the relationship against firm performances. Based on the data companies will paying average $44 \%$ of their earnings as dividends. Standard deviation of $30 \%$ will explain that dividend payout giving values between $14 \%$ and $74 \%$. Dividend payout, capital structure, firm size, EVA, and stock return have skewness between +02 range and kurtosis value less than 5, which indicate that above variables are normally distributed.

Based on the results of the correlation analysis (See Appendix 05) we identify that there is a positive relationship between dividend payout and firm market and financial performances. Results were highly significant at $1 \%$ level. This indicate that firm dividend payout will positively influence the firm performances.

Table 2: Summary of Descriptive Statistics

\begin{tabular}{c|cccccccc}
\hline Variable & Obs. & Min & Max & Mean & Median & SD & Skewn. & Kurt. \\
\hline DIVPAY & 150 & 0 & 1.0555 & 0.44 & 0.3689 & 0.30 & 0.60 & 2.37 \\
EARNVOL & 150 & -1.01 & 15.17 & 1.88 & 0.4628 & 3.84 & 2.50 & 8.49 \\
NWC & 150 & -19556 & 4389.41 & -2548.50 & -634.04 & 5667.41 & -1.65 & 5.47 \\
CAPSTR & 150 & 0 & 1.83 & 0.52 & 0.39 & 0.51 & 1.20 & 3.59 \\
SIZE & 150 & 9.9662 & 11.32 & 10.61 & 10.54 & 0.44 & 0.19 & 1.79 \\
ROE & 150 & 0.0142 & 0.91 & 0.21 & 0.12 & 0.25 & 2.02 & 5.74 \\
ROA & 150 & 0.0055 & 0.46 & 0.11 & 0.06 & 0.12 & 1.95 & 5.71 \\
EVA & 150 & -10972 & 2888.67 & -2116.94 & -645.06 & 4117.42 & -1.003 & 3.01 \\
STKRET & 150 & -0.40 & 0.54 & -0.0005 & -0.03 & 0.25 & 0.62 & 2.88 \\
MVA & 150 & -33133 & 145289 & 14204.4 & 2857.6 & 42067.7 & 1.84 & 6.14
\end{tabular}

Table 3: Regression results

\begin{tabular}{|c|c|c|c|c|c|c|c|c|c|c|}
\hline & \multicolumn{2}{|c|}{ Model 1 (R) } & \multicolumn{2}{|c|}{ Model 2 (F) } & \multicolumn{2}{|c|}{ Model 3 (F) } & \multicolumn{2}{|c|}{ Model 4 (F) } & \multicolumn{2}{|c|}{ Model 5 (F) } \\
\hline & Coeff. & $\begin{array}{c}\mathbf{P} \\
\text { Value }\end{array}$ & Coeff. & P Value & Coeff. & $\begin{array}{c}\mathbf{P} \\
\text { Value }\end{array}$ & Coeff. & P Value & Coeff. & $\begin{array}{c}\mathbf{P} \\
\text { Value }\end{array}$ \\
\hline $\mathrm{C}$ & 0.6581 & 0.250 & 02649 & $0.000^{* * *}$ & -0.23 & 0.800 & 59.43 & $0.000^{* * *}$ & -14035 & $0.003 * *$ \\
\hline DIVPAY & 0.1687 & $0.048 * *$ & 048.97 & 0.492 & 0.22 & $0.006^{* *}$ & 1.0656 & $0.025 * *$ & 673.35 & $0.032 * *$ \\
\hline EARNVOL & 0.0209 & $0.040 * *$ & 20.00 & 0.638 & $0.0001 * * *$ & 0.820 & 0.0028 & 0.142 & 0.78 & 0.967 \\
\hline NWC & $\begin{array}{l}- \\
0.0014\end{array}$ & 0.811 & .73 & 0.171 & 0.0138 & $0.002 * *$ & $\begin{array}{l}- \\
0.0723\end{array}$ & $0.025 * *$ & 0.75 & $\begin{array}{l}0.000 * * \\
*\end{array}$ \\
\hline CAPSTR & $\begin{array}{l}- \\
0.0007\end{array}$ & 0.228 & 22832 & $0.006^{* *}$ & 0.0022 & $0.020 * *$ & $\begin{array}{l}- \\
0.0178\end{array}$ & $0.002 * *$ & $\begin{array}{l}1467.8 \\
5\end{array}$ & $\begin{array}{l}0.000 * * \\
*\end{array}$ \\
\hline SIZE & $\begin{array}{l}- \\
0.0696\end{array}$ & 0.200 & 0594.6 & $0.000 * * *$ & 0.0338 & 0.686 & $\begin{array}{l}- \\
5.5567\end{array}$ & $0.000 * * *$ & $\begin{array}{l}1203.4 \\
8\end{array}$ & $0.007 * *$ \\
\hline Y 2015 & - & - & 4548 & 0.332 & - & - & 0.1462 & 0.539 & - & - \\
\hline Y 2016 & - & - & 5422 & 0.259 & - & - & 0.5851 & $0.018 * *$ & - & - \\
\hline
\end{tabular}




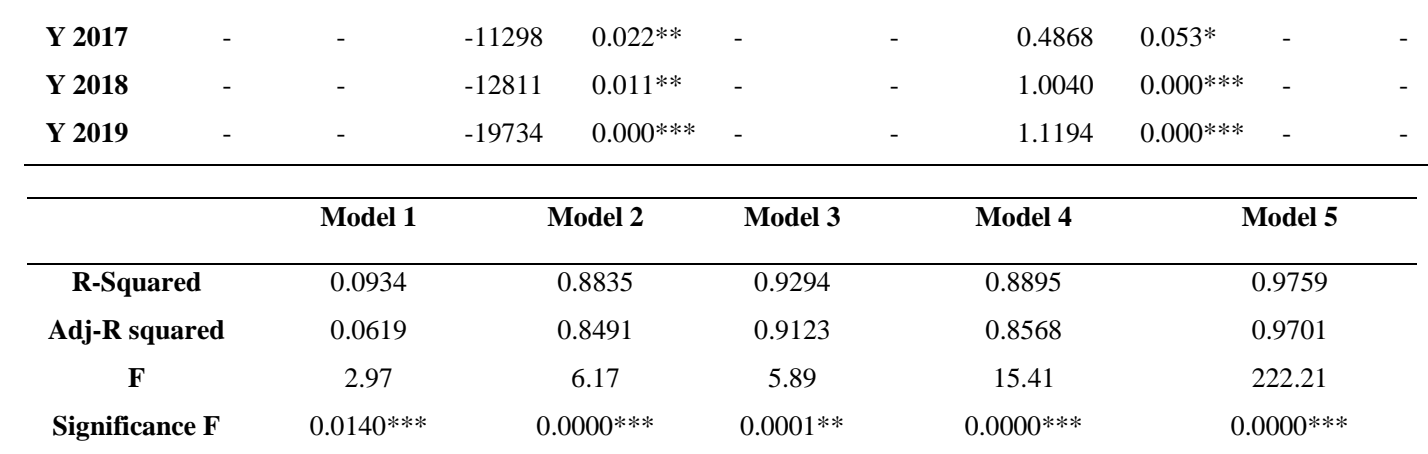

Note: $(\mathbf{R})$ Random effect model, $(\mathrm{F})=$ Fixed effect model $* * *$ Significant at $1 \%$ Level, ** Significant at 5\% Level, * Significant at $10 \%$ Level

Apart from the dividend payout earning volatility positively influence the firm market performance and net working capital positively influence the both firm financial and market performances. Firm capital structure is negatively correlated with all dependent variables. This depict that greater the company use external funds through borrowings, it will lead to lowering the firm financial and market performances. If the regression is developed with including all the independent and control variables as one liner regression and the correlation is higher than 0.7 , it indicates presence of multicollinearity. Based on the obtained results there is not any significant correlation between independent variables, which indicate no multicollinearity. Therefore, all the variables have been continued for multiple regression.

Table (Table 3) summarizes the findings of the panel regression model applied for the five models.

Results of this this regression model 01(stock return as the measure of performance) indicate that impact of dividend payout in firm stock return is significant at 5\% level. Earning volatility is also having significant positive influence on stock return suggesting that volatility of the earnings is an influencing factor to the stock return. Adjusted R squared reflect the explanatory power of the model and it shows very weak $(6.19 \%)$ variation of stock return from the independent variables in the model. Model 1 findings are significant at 5\% which reveals that dividend payout, earning volatility are significantly and positively influence the stock return of the companies listed in CSE.

Model 02 ((Market value added (MVA) as the measure of performance) regression results indicate that only capital structure and the firm size is having significant influence on MVA. The relationship between firm capital structure and the MVA is negative which shows that whenever the firm increase their level of debts MVA of the firm will decrease. Based on the Pre-tests, the appropriate model for the model 2 is time fixed effect model. In the time fixed effect model, it will introduce dummy variables to each year variables in the model. According to the regression results probability values of the year 2017, 2018 and 2019 are significant at the 5\% Level. It shows that in those specific years, the effect of independent variables on firm MVA is significant. The explanatory power of the model 2 is $84.91 \%$. That is, around $85 \%$ of variation of the MVA are explained by the combined influence of independent variables in the model 2. Overall model is significant reveals that capital structure and firm size are significant components that will determine the MVA of the firms listed in CSE.

According to the test results of the model 03 (Return on Equity (ROE) as measure of performance) it's clear that ROE of the firms listed in CSE is mostly explained by payout ratio, Net working capital and the capital structure of the firm are significant and evident that, dividend payout will positively and significantly influence the firm ROE. Adjusted R squared of the model reflect that $91.23 \%$ variability in the ROE is explained by 
the selected variables in the model and the overall model is significant. As a result, this implies that dividend payout, net working capital and capital structure of the firm are reasonably statistically significant components which support in determining the ROE of the firms listed in CSE.

Results of the regression model 04 (Return on Assets (ROA) as measure of performance) shows that dividend payout, net working capital, capital structure and the firm size having significant influence on ROA. The impact of dividend payout on ROA is positive which shows that whenever the firm increase their dividend payout, firm ROA will increase. Furthermore, results reflect that firm net working capital, capital structure and firm size will have significant but negative influence on firm Return on assets. Additionally, as model 04 runs with time fixed effect model, probability values of the year 2016, 2018 and 2019 are significant at the 5\% Level. That is, it shows that in those specific years, the effect of independent variables on firm ROA is significant. The adjusted R2 is $85.68 \%$ and the overall model is significant at $5 \%$ revealing that dividend payout, net working capital, capital structure and firm size are significant components that will determine the ROA of the firms the listed in CSE.

Model 05 (Market Value Added (MVA) as measure of performance) reflecting that economic value added of the firms listed in CSE is mostly explained by payout ratio, Net working capital, firm capital structure and the size of the firm. Those variables are statically significant. Therefore, this will provide evidence that high level of dividend payout will leads to increase the firm economic value added. Adjusted R squared of the model reflect that $97.01 \%$ variability in the EVA is explained by the selected variables in the model. Overall model is significant and as a result, this implies that dividend payout, net working capital, capital structure and size of the firm are reasonably significant components which support in determining the EVA of the firms listed in CSE. Based on the above findings, the acceptance of the hypotheses can be summarized in below table 04;

Table 04: Summary of the Hypotheses

\begin{tabular}{ll}
\hline \multicolumn{1}{c}{ Hypotheses } & Response \\
\hline $\begin{array}{l}\mathrm{H}_{1} \text { : There is a significant } \\
\text { positive influence of dividend } \\
\text { payout on firm Stock return }\end{array}$ & $\begin{array}{l}\text { Do not } \\
\text { reject }\end{array}$ \\
$\begin{array}{l}\mathrm{H}_{2} \text { : There is a significant positive } \\
\text { influence of dividend payout on } \\
\text { firm Market Value Added }\end{array}$ & $\begin{array}{l}\text { Do not } \\
\text { accept }\end{array}$ \\
$\mathrm{H}_{3}$ : There is a significant positive \\
influence of dividend payout on \\
$\begin{array}{l}\text { firm Return on equity. } \\
\text { reject }\end{array}$ \\
$\begin{array}{l}\mathrm{H}_{4} \text { : There is a significant } \\
\text { positive influence of dividend } \\
\text { payout on firm Return on }\end{array}$ & $\begin{array}{l}\text { Do not } \\
\text { Assets. }\end{array}$ \\
$\begin{array}{l}\mathrm{H}_{5} \text { : There is a significant } \\
\text { positive influence of dividend } \\
\text { payout on firm Economic Value } \\
\text { added }\end{array}$ & $\begin{array}{l}\text { Do not } \\
\text { reject }\end{array}$ \\
\hline
\end{tabular}

\section{CONCLUSION AND RECOMMENDATION}

This study investigates the impact of dividend policy on firm performance using both financial and market performance indicators in Sri Lankan context. The sample of this study consist with 25 listed entities at CSE from 2014 to 2019 and it covers $50 \%$ of the market capitalization as at March 2020. The results were generated using Stata 13. We used five dependent variables namely, stock return, Market Value Added (MVA), Return on equity (ROE), Return on asset (ROA) and Economic Value Added (EVA) in order to measure the impact of dividend payout on firm financial and market performance. We employed Panel regression model to identify the above impact and therefore, we used 05 different models.

The findings of this study revealed that there is a positive significant influence of dividend payout on firm stock return. Therefore, it provides evidence for supporting dividend 
relevance theory (Lintner,1956; Gordon,1962; Walter,1963) which concludes direct correlation between firm dividend payout policy and stock price. Furthermore, model 01 has identified that earning volatility has significant positive influence on firm stock return while insignificant negative influence of net working capital, capital structure and the firm size on stock return.

Dividend payout, earning volatility and net working capital have an insignificant positive influence on MVA while firm capital structure and size have a significant influence on MVA. These findings are in line with the evidence provided by Gharaibeh, (2017) who is conclude that dividend payout is not a significant determinants of the market value of the firm. Further, the analysis of data shows that, there is a positive significant influnce of dividend payout on firm Retun on Asset and Retun on equity which will also support the dividend relevance theory and the sector findings of the Wijekoon and Senevirathna (2019) and Priya, and Nimalathasan, (2013). Study also indicate that, capital structure has a positive influnce on Return on equity that will support the finds of Hamada, (1969) who argued that returns of the firm will increase with the leverage.

This study also reveals that relationship between Return on asset and earning volatility is positive but not significant and Net working capital, firm capital structure and firm size is having significant negative influence on firm ROA. EVA considered to be the best known of the shareholder value metrix (Brown, 2000). Positive Economic Value Added indicate the firm has created value for its shareholders over the period. In otherhand if the EVA is negative its shows that the firm is destroying shareholders' wealth. The findings of this study show that that dividend payout is having significant positive influence on firm Economic Value Added which reveals that higher dividend payout will increasing shareholder'value. Therefore our finding are consisting with Dividend relevance theory (Gordon,1963 ). Study also has identified that net working capital, firm capital structure and firm size is having a positive significant influnce on firm EVA while earning volatility is having insignificant positive influnce on firm EVA.

It is concluded from the study that high dividend payout will significantly influence the firm market and financial performance of the firms listed CSE. Therefore, our findings have several implications investors, management, and policy decision makers. Henceforth, the stakeholders at large need to pay more attention on company's dividend policies since it will significantly effect on firm financial and market performances indicators.

Nevertheless, our study having few limitations. Firstly, the sample is restricted to 25 listed companies and it excludes the Banking and finance sector entities. However, our sample represents the $50 \%$ of total market capitalization at CSE. Secondly, measurement of dividend policy is limited only to the dividend payout ratio. Furthermore, our sample is restricted to only to six years which can be extended in the future studies. Therefore, we suggest future researchers to increase the sample and sample period. Additionally, future studies can consider to include the banking and insurance sector and to conduct a comparison with non-bank financial firms to identify any significant difference in investigating the impact on dividend policy on firm performance.

\section{REFERENCE}

Abor, M. A. (2006). Determinants of dividend payoutratios in Ghana. The Journal of Risk Finance, Vol. 7 No. 2, 2006pp. 136-145.

Ajanthan, A. (2013). The Relationship Between Dividend Payout and Firm Profitability:A Study of selected hotels and restaurant companies in sri lanka. International Journal of Scientific and Research Publications, Volume 3, Issue 6.

Allayannis, G., \& Weston, J. P. (2003). Earnings volatility, cashflow volatility, and rm value. 
Al-Twaijry, a. (2007). Dividend policy and payout ratio: Evidence from the Kuala Lumpur stock exchange. Journal of Risk Finance. 8, pp.349-363.

Amollo, K. O. (2016). The effects of dividend policy on firm value for commercial banks in Kenya (Doctoral dissertation, University Of Nairobi).

Anton, S. G. (2016). The Impact Of Dividend Policy On Firm Value. A Panel Data Analysis Of Romanian Listed Firms. Journal of Public Administration, Finance and Law, pp.107-112.

Balagobei, S. (2015). Dividend policy and shareholders' wealth of listed manufacturing companies in Sri Lanka. Journal of Economics and Sustainable Development, 6(19), 33-38.

Balasundaram,N. (2013). Determinants of profitability:A case study of listed manufacturing firms in Sri Lanka. Merit Research Journal of Art, Social Science and Humanities, 16.

Brealey, R. A., Myers, S. C., Allen, F., \& Mohanty, P. (2012). Principles of corporate finance. Tata McGraw-Hill Education.

Brown, R., \& Pierce, B. (2000, April). The empirical validity of EVA. In Management Accounting Research Conference, at London School of Economics, London.

Bhattacharya, S. (1979). Imperfect Information, Dividend Policy, and "The Bird in the Hand" Fallacy. The Bell Journal of Economics, Vol.10 (1),pp.259-270.

Black, F. (1976). Dividend Puzzle. Journal of portfolio management, Vol. 2 (2), pp. 5-8

Chen, G., Firth, M., \& Gao, N. (2002). The information content of concurrently announced earnings, cash dividends, and stock dividends: an investigation of the Chinese stock market. Journal of International Financial Management \& Accounting, 13(2), 101-124.
David, I. (2011). Dividend policy Decision. Behavioral Finance: Investors, Corporations, and Markets, 435-451.

Fama, E.(1991). Efficient Capital Markets II, Journal of Finance, Vol. 46 (5), pp.15751671.

Gharaibeh, A. A. (2017). actors influencing firm value as measured by the Tobin's Q: Empirical evidence from the Saudi Stock Exchange . International Journal of Applied Business and Economic Research, 333-358.

Gordon, M. J. (1963). Optimal Investment And Financing Policy. The Journal of Finance, Vol. 18(2),pp. 264-272.

Hamada, R. (1969), Portfolio analysis, market equilibrium and corporate finance, Journal of Finance, Vol. 24, pp. 13-31.

Hussainey, K., Mgbame, C. O., \& ChijokeMgbame, A. M. (2011). Dividend policy and share price volatility: UK evidence. The Journal of risk finance.

Irum, M., Rafique, M., \& Hassan, A. (2012). Effect of dividend announcement on share prices of petroleum industry of Pakistan. Journal of Basic and Applied Scientific Research, 2(7), 6503-6511.

Lintner, J. (1956). Distribution of Incomes of Corporations Among Dividens, Retained Earnings, and. The American Economic Review, Vol. 46 (2), 97-113.

Majanga, B. B. (2015). The dividend effect on stock price- An empirical analysis of Malawi listed companies. Accounting and Finance Research, pp.99-105.

Manjunatha, K. (2018). Dividend Policy And Financial Performance Of Indian Cement Companies - An Empirical Study. Journal of Management (JOM), pp.157-164.

Masum, A. A. (2014). Dividend Policy and Its Impact on Stock Price - A Study on Commercial Banks Listed in Dhaka Stock Exchange. Global Disclosure of Economics and Business, Vol.3, pp.9-17. 
Miller, R. and F. Modigliani (1961), 'Dividend Policy, Growth and the Valuation of Shares', Journal of Business, Vol. 34 (4), pp. 411-33.

Modigliani, F., and M. Miller. (1958). "The Cost of Capital, Corporation Finance and the Theory of Investment." American Economic Review, 48 (3), pp.261-97.

Mohammed Amidu, J. A. (2006). Determinants of dividend payoutratios in Ghana. The Journal of Risk Finance. Vol. 7 (2), 2006, pp.136-145.

Murugesu, T. (2017). An Analysis of Dividend Policy and Market Value of Listed Manufacturing comapnies in sri lanka. International Journal of Scientific and Engineering Research. Vol 8 (6)

Narang, M. (2018). Impact of capital structure on firm performance: A study of listed firms on national stock exchange. International Journal of Advanced Educational Research, 3(1), 251-254.

Olufade, S. (2018). Impact of dividend policy on firm performance in the food and beverage industry: Comparison between Nigeria and Finland.

Paviththira, R. (2015). Impact of Dividend Policy on Corporate Profitability: Evidence from Listed Beverage Food and Tobacco Companies on Colombo Stock Exchange (CSE) in Sri Lanka. 12th International Conference on Business Management (ICBM) , pp.1-15.

Perera, Anne. (2020). ASURUMUNI ANNE SHIRANTHI INDIKA PERERA Impact of Dividend Policy on Firm Financial Performance Anotācija Maǵistra darba autors: Asurumuni Anne Shiranthi Indika Perera Annotation.
Priya, K. and Nimalathasan, B (2013), Dividend Policy Ratios and Firm Performance:a case study of Selected Hotels \& Restaurants in Sri Lanka,. Global Journal of Commerce and Management Perspective, Vol.2(6), pp.16-22.

Sharif, S. P., \& Lai, M. M. (2015). The effects of corporate disclosure practices on firm performance, risk and dividend policy. International Journal of Disclosure and Governance, 12(4), 311-326.

Shefrin, H. (2010). Behavioralizing Finance Foundations and trends in finance. Vol.4(1),pp.1-184.

Sugathadasa, Kaushalya. (2018). The Impact of Dividend Policy on Share Price Volatility: Empirical Evidence with Colombo Stock Exchange in Sri Lanka. 7. 352-359. 10.24940/ijird/2018/v7/i8/131041-3169822-SM.

Uddin, M. H., \& Chowdhury, G. M. (2005). Effect of dividend announcement on shareholders' value: Evidence from Dhaka Stock Exchange. Journal of business research, 7(1), 61-72.

Uwuigbe, U., Jafaru, J. and Ajayi, A. (2012). Dividend Policy and Firm Performance: A Study of Listed Firms in Nigeria. Accounting and Management Information Systems, 11(3), 442-454.

Walter, J. E. (1963). Dividend policy: its influence on the value of the enterprise. The Journal of finance, 18(2), 280-291.

Wijekoon W. M. S. S. Senevirathna L. D. N. (2019), Impact of Dividend Policy on Firm Performance Evidence from Listed Companies in Colombo Stock Exchange, Global Scientific Journals, Vol7 (10), pp. 225-23 


\section{Appendices}

Appendix 01: Levin-Lin-Chu unit-root test results

\begin{tabular}{|c|c|c|c|c|c|c|c|c|c|c|}
\hline Variable & DIVPAY & EARNVOL & NWC & CAPSTR & SIZE & ROE & ROA & EVA & STKRETURN & MVA \\
\hline $\begin{array}{c}\text { Levin-Lin- } \\
\text { Chu Prob. }\end{array}$ & 0.00 & 0.00 & 0.00 & 0.00 & 0.00 & 0.00 & 0.00 & 0.00 & 0.00 & 0.00 \\
\hline
\end{tabular}

Appendix 02: Multicollinearity test results - VIF

\begin{tabular}{|l|c|c|c|c|c|c|c|c|c|c|}
\hline & \multicolumn{2}{|c|}{ Model 1 (R) } & \multicolumn{2}{c|}{ Model 2 (F) } & \multicolumn{2}{c|}{ Model 3 (R) } & \multicolumn{2}{c|}{ Model 4 (F) } & \multicolumn{2}{c|}{ Model 5 (R) } \\
\cline { 2 - 12 } & Tolerance & VIF & Tolerance & VIF & Tolerance & VIF & Tolerance & VIF & Tolerance & VIF \\
\hline DIVPAY & 0.675942 & 1.48 & 0.922258 & 1.08 & 0.805713 & 1.24 & 0.704076 & 1.42 & 0.922245 & 1.08 \\
\hline EARNVOL & 0.944620 & 1.06 & 0.924361 & 1.08 & 0.945761 & 1.06 & 0.946442 & 1.06 & 0.924360 & 1.08 \\
\hline NWC & 0.637817 & 1.57 & 0.665077 & 1.50 & 0.793327 & 1.26 & 0.685865 & 1.46 & 0.665102 & 1.50 \\
\hline CAPSTR & 0.880931 & 1.14 & 0.867968 & 1.15 & 0.862448 & 1.16 & 0.868610 & 1.15 & 0.868022 & 1.15 \\
\hline FIRM SIZE & 0.841863 & 1.19 & 0.677809 & 1.48 & 0.842741 & 1.19 & 0.838996 & 1.19 & 0.677810 & 1.48 \\
\hline Mean VIF & & 1.29 & & 1.26 & & 1.18 & & 1.26 & & 1.26 \\
\hline
\end{tabular}

Appendix 03: Model Selection

\begin{tabular}{|l|c|c|c|c|}
\hline \multicolumn{1}{|c|}{ Model } & $\begin{array}{c}\text { Hausman } \\
\text { Test }(\mathrm{P})\end{array}$ & Fixed/Random & $\begin{array}{c}\text { LM Test/ Fixed Time effect } \\
(\mathrm{P})\end{array}$ & Appropriate Model \\
\hline Model 1 (R) & 0.1179 & Random Effect & 0.3236 & Simple OLS Regression \\
\hline Model 2 (F) & 0.0000 & Fixed Effect & 0.0052 & Fixed Time effect \\
\hline Model 3 (R) & 0.0000 & Fixed Effect & 0.8345 & Fixed Effect \\
\hline Model 4 (F) & 0.0075 & Fixed Effect & 0.0005 & Fixed Time effect \\
\hline Model 5 (R) & 0.0000 & Fixed Effect & 0.0909 & Fixed Effect \\
\hline
\end{tabular}

Appendix 04: Jarque- Bera test for normality

\begin{tabular}{|l|l|l|l|l|l|}
\hline Model & Model 1 (R) & Model 2 (F) & Model 3 (R) & Model 4 (F) & Model 5 (R) \\
\hline Jarque- Bera & 3.591790 & 4.300071 & 0.757369 & 4.408725 & 2.838173 \\
\hline Probability & 0.165979 & 0.116442 & 0.684751 & 0.110321 & 0.241935 \\
\hline
\end{tabular}

Appendix 05: correlation analysis

\begin{tabular}{|c|c|c|c|c|c|c|c|c|c|c|}
\hline & STKRetu & MVA & ROE & ROA & EVA & $\begin{array}{l}\text { DIV } \\
\text { PAY }\end{array}$ & $\begin{array}{c}\text { EARN } \\
\text { VOL }\end{array}$ & NWC & $\begin{array}{l}\text { CAP } \\
\text { STR } \\
\end{array}$ & SIZE \\
\hline STK Return & 1 & & & & & & & & & \\
\hline MVA & $\begin{array}{l}0.12 \\
0.00 \\
\end{array}$ & 1 & & & & & & & & \\
\hline ROE & $\begin{array}{l}0.08 \\
0.37 \\
\end{array}$ & $\begin{array}{l}0.50 \\
0.00 \\
\end{array}$ & 1 & & & & & & & \\
\hline ROA & $\begin{array}{l}0.08 \\
0.36 \\
\end{array}$ & $\begin{array}{l}0.44 \\
0.00\end{array}$ & $\begin{array}{l}0.53 \\
0.00\end{array}$ & 1 & & & & & & \\
\hline EVA & $\begin{array}{l}0.16 \\
0.06 \\
\end{array}$ & $\begin{array}{l}0.31 \\
0.00 \\
\end{array}$ & $\begin{array}{l}0.43 \\
0.00 \\
\end{array}$ & $\begin{array}{l}0.43 \\
0.00 \\
\end{array}$ & 1 & & & & & \\
\hline DIVPAY & $\begin{array}{l}0.22 \\
0.01 \\
\end{array}$ & $\begin{array}{l}0.42 \\
0.00 \\
\end{array}$ & $\begin{array}{l}0.61 \\
0.00 \\
\end{array}$ & $\begin{array}{l}0.51 \\
0.00 \\
\end{array}$ & $\begin{array}{l}0.33 \\
0.00 \\
\end{array}$ & 1 & & & & \\
\hline $\begin{array}{c}\text { EARN } \\
\text { VOL }\end{array}$ & \begin{tabular}{|l|}
0.13 \\
0.11 \\
\end{tabular} & $\begin{array}{c}0.097 \\
0.24 \\
\end{array}$ & $\begin{array}{c}-0.03 \\
0.65 \\
\end{array}$ & $\begin{array}{c}-0.04 \\
0.59 \\
\end{array}$ & $\begin{array}{l}-0.03 \\
0.66 \\
\end{array}$ & $\begin{array}{c}-0.06 \\
0.49 \\
\end{array}$ & 1 & & & \\
\hline NWC & $\begin{array}{l}0.15 \\
0.06 \\
\end{array}$ & $\begin{array}{l}0.43 \\
0.00 \\
\end{array}$ & $\begin{array}{l}0.54 \\
0.00 \\
\end{array}$ & $\begin{array}{l}0.20 \\
0.01 \\
\end{array}$ & $\begin{array}{l}0.66 \\
0.00 \\
\end{array}$ & $\begin{array}{l}0.55 \\
0.00 \\
\end{array}$ & $\begin{array}{l}0.09 \\
0.30 \\
\end{array}$ & 1 & & \\
\hline $\begin{array}{l}\text { CAP } \\
\text { STR } \\
\end{array}$ & $\begin{array}{l}-0.16 \\
0.05 \\
\end{array}$ & $\begin{array}{c}-0.25 \\
0.00 \\
\end{array}$ & $\begin{array}{c}-0.12 \\
0.15 \\
\end{array}$ & $\begin{array}{c}-0.15 \\
0.07 \\
\end{array}$ & $\begin{array}{l}-0.35 \\
0.00 \\
\end{array}$ & $\begin{array}{c}-0.23 \\
0.01 \\
\end{array}$ & $\begin{array}{l}0.07 \\
0.40\end{array}$ & $\begin{array}{c}-0.24 \\
0.00 \\
\end{array}$ & 1 & \\
\hline $\begin{array}{l}\text { FIRM } \\
\text { SIZE }\end{array}$ & $\begin{array}{c}-0.15 \\
0.07 \\
\end{array}$ & $\begin{array}{l}0.05 \\
0.54 \\
\end{array}$ & $\begin{array}{l}0.22 \\
0.01 \\
\end{array}$ & $\begin{array}{c}-0.23 \\
0.01 \\
\end{array}$ & $\begin{array}{l}-0.56 \\
0.00 \\
\end{array}$ & $\begin{array}{c}-0.21 \\
0.01 \\
\end{array}$ & $\begin{array}{l}0.15 \\
0.06 \\
\end{array}$ & $\begin{array}{c}-0.29 \\
0.00 \\
\end{array}$ & $\begin{array}{l}0.29 \\
0.00 \\
\end{array}$ & 1 \\
\hline
\end{tabular}

